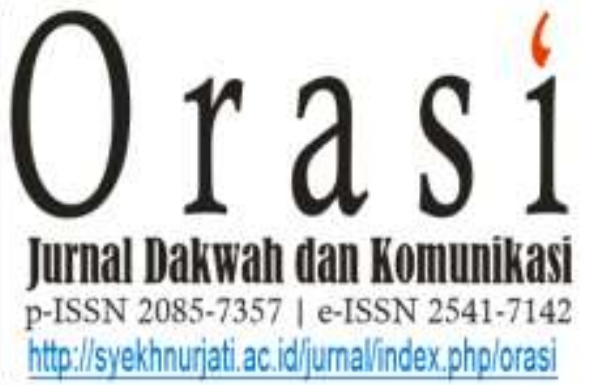

Volume 11 No. 2 Desember 2020

\title{
MANAJEMEN ISU RUANGGURU TERHADAP POLEMIK KARTU PRAKERJA
}

\section{MANAGEMENT ISSUES OF RUANGGURU ON PRAKERJA CARD POLEMICS}

\author{
1,a)Adinda Nada Shofa Nasution, 1,b)Farhanah Khalid, \\ 1,c)Ayulia Karisma Putri \\ ${ }^{1}$ Program Studi Magister Ilmu Komunikasi, Universitas Paramadina

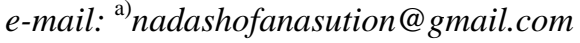 \\ e-mail: b) farhanah.khalid@gmail.com \\ e-mail: ${ }^{\mathrm{c})}$ ayuliarism@gmail.com
}

\begin{abstract}
ABSTRAK
Keterlibatan Ruangguru dalam program Kartu Prakerja menimbulkan beredarnya isu negatif tentang penunjukan Ruangguru sebagai penyedia pelatihan lewat platform Skill Academy. Isu tersebut menimbulkan berbagai asumsi/persepsi di tengah masyarakat yang menduga bahwa penunjukan Ruangguru tak lepas dari privilege yang dimiliki CEO Ruangguru Adamas Syah Belva Devara, yang pada saat itu juga menjabat sebagai Staf Khusus Presiden Indonesia. Dari fenomena tersebut, penelitian ini bermaksud memberikan gambaran tentang bagaimana manajemen isu yang dilakukan oleh Ruangguru dengan menggunakan analisis framing terhadap teks pernyataan resmi dari Ruangguru, baik melalui "Surat Terbuka Belva Devara, CEO Ruangguru" maupun laman tanya jawab khusus yang terintegrasi dengan situs web Ruangguru. Metode penelitian yang digunakan adalah kualitatif dengan teknik pengumpulan data teks media. Data akan diulas menggunakan analisis framing menggunakan model Entman. Untuk cakrawala pemahaman lebih terbuka, hasil analisis akan dikategorikan ke dalam jenis model framing Hallahan. Meskipun metode ini memang lebih umum digunakan dalam bidang jurnalistik, namun framing bermanfaat bagi organisasi dalam hal menyusun pesan yang dapat diterima oleh publik dan menghadirkan citra positif bagi organisasi guna keberlangsungan organisasi. Dengan mengimplementasikan
\end{abstract}


manajemen isu melalui framing, Ruangguru dapat memposisikan diri dalam polemik ini dengan baik sehingga tidak mengakibatkan polemik berkepanjangan.

Kata Kunci: Framing, Isu, Ruangguru, Kartu Prakerja

\begin{abstract}
Ruangguru's involvement in the Kartu Prakerja Program caused negative issues because Ruangguru was chosen as a training provider through the Skill Academy platform. This issue raised various public assumptions/perceptions assuming that Ruangguru was chosen because of the CEO's privilege, Adam Syah Belva Devara, who served as one of the special staff to the President of Indonesia. From this phenomenon, this study aimed to provide an overview of how the issue management carried out by Ruangguru by using framing analysis of Ruangguru's official statement texts, either from "Surat Terbuka Belva Devara, CEO Ruangguru" or a FAQ page integrated with the Ruangguru website. The writers used qualitative research method with media text data collection techniques. The data were reviewed using framing analysis based on the Entman model. For more insights, the results of the analysis were categorized into Hallahan framing model types. Even though this method is commonly used in journalistic studies, framing gives benefits to create messages that can be undserstood by public and create a positive image for the organization in order to keep its continuity. By implementing the issue management through framing, Ruangguru was able to handle the polemic well and prevent it from getting worse.
\end{abstract}

Keywords: Framing, Issue, Ruangguru, Kartu Prakerja

\section{Pendahuluan}

Pandemi virus Covid-19 tak hanya mengancam kesehatan manusia, tetapi juga berimbas pada sektor ekonomi. Banyak usaha mengalami penurunan pemasukan, hingga ada pula yang gulung tikar. Dalam skenario terberat, Centre of Reform on Economics (CORE) Indonesia memperkirakan jumlah pengangguran terbuka bisa meningkat hingga 9,35 juta orang. Dikutip dari Kompas.com, pengamat ekonomi dari Institute for Development of Economics and Finance (INDEF), Enny Hartati, mengatakan pemerintah harus fokus pada upaya memutus penyebaran Covid-19 dan memberi bantuan serta perlindungan bagi mereka yang terdampak Covid-19 secara sosial dan ekonomi (Rizal 2020).

Menyikapi berbagai keluhan korban PHK dan tuntutan berbagai pihak, pemerintah Republik Indonesia (RI) membuka secara resmi pendaftaran Kartu Prakerja pada 11 April 2020 lalu. Program yang semula diperuntukkan para pencari kerja berusia muda, belakangan skenarionya diperluas untuk meringankan karyawan yang terdampak PHK. Setiap pemegang Kartu Prakerja akan mendapatkan bantuan senilai Rp3.550.000,00 (tiga juta lima ratus lima puluh ribu rupiah) yang terdiri dari biaya pelatihan senilai $\mathrm{Rp} 1$ juta dan biaya menuntaskan pelatihan sebesar 
Rp 2,4 juta yang ditransfer bertahap selama empat bulan (Putsanra 2020).

Kisruh mulai muncul saat banyak pendaftar mengalami kendala dalam mengakses laman pendaftaran. Tak hanya itu, kontroversi Kartu Prakerja terus bergulir ke berbagai isu lain. Salah satunya terkait manfaat pelatihan dalam kondisi wabah. Banyak pihak menilai korban PHK lebih membutuhkan sembako dan uang tunai ketimbang pelatihan yang belum tentu bisa menyerap kebutuhan lapangan kerja karena banyak perusahaan yang juga mengalami kesulitan ekonomi.

Materi yang diberikan oleh mitra yang terdiri dari berbagai lembaga penyedia pelatihan pun dinilai tidak relevan karena sudah banyak materi sejenis yang beredar di Youtube. Terlebih banyak pihak yang menganggap harga yang dibandrol terlampau mahal untuk satu sesi pelatihan. Sejumlah polemik juga dilontarkan terkait efektifitas pelatihan digital untuk beberapa keterampilan yang membutuhkan praktik langsung karena diketahui bahwa sertifikat keterampilan tersebut bukan dikeluarkan oleh dari pihak/lembaga profesional yang tersertifikasi dan berkompeten di bidangnya, melainkan dikeluarkan oleh penyedia pelatihan tersebut, diantaranya Ruangguru.

Keterlibatan Ruangguru dalam program Kartu Prakerja ini pun akhirnya berujung pada beredarnya isu negatif di berbagai media. Isu tersebut terus digoreng di media massa hingga berkembang ke berbagai hal, termasuk berembusnya isu tentang privilege bahwa penunjukan Ruangguru sebagai penyedia pelatihan lewat platform Skill Academy diperoleh tanpa melalui proses tender dan verifikasi, melainkan dilakukan dengan metode penunjukan langsung.

Hingga akhirnya, polemik ini mendorong Devara pamit dari jabatannya sebagai Staf Khusus di pemerintahan. Secara resmi Devara mengumumkan pengunduran dirinya kepada khalayak dalam sebuah unggahan akun media sosial Instagram miliknya (@belvadevara), yang bertajuk "Surat Terbuka Belva Devara, CEO Ruangguru" pada 21 April 2020 (Devara 2020). Dalam surat tersebut Devara juga menyinggung tentang penunjukan Ruangguru yang telah menjalani proses verifikasi Kartu Prakerja sesuai prosedur. Ia pun mengatakan, alasan pengunduran dirinya adalah karena tidak ingin menimbulkan polemik berkepanjangan. Secara lebih lengkap, berikut isi surat pengunduran diri Belva Devara sebagai Staf Khusus Presiden RI:

"Surat Terbuka Belva Devara, CEO Ruangguru.

Assalamualaikum warahmatullahi wabarakaatuh. Salam sejahtera untuk kita sетиа.

Semoga di masa pandemi ini kita diberikan kesehatan dan kekuatan dari Allah yang Maha Penyayang.

Berikut ini saya sampaikan informasi terkait pengunduran diri saya sebagai Staf Khusus Presiden. Pengunduran diri tersebut telah saya sampaikan dalam bentuk surat kepada Bapak Presiden tertanggal 15 April 2020, dan disampaikan langsung ke Presiden pada tanggal 17 April 2020.

Seperti yang telah dijelaskan oleh Kementerian Koordinator 
Perekonomian dan Manajemen Pelaksana Kartu Prakerja (PMO), proses verifikasi semua mitra Kartu Prakerja sudah berjalan sesuai aturan yang berlaku, dan tidak ada keterlibatan yang memunculkan konflik kepentingan. Pemilihan kelas pun dilakukan langsung oleh peserta pemegang Kartu Prakerja.

Namun, saya mengambil keputusan yang berat ini karena saya tidak ingin polemik mengenai asumsi/persepsi publik yang bervariasi tentang posisi saya sebagai Staf Khusus Presiden menjadi berkepanjangan, yang dapat mengakibatkan terpecahnya konsentrasi Bapak Presiden dan seluruh jajaran pemerintahan dalam menghadapi masalah pandemi COVID-19.

Saya berterima kasih kepada Bapak Presiden Joko Widodo yang telah memahami dan menerima pengunduran diri saya.

Walau singkat, sungguh banyak pengalaman dan pelajaran yang saya dapatkan dari pekerjaan sebagai Stafsus Presiden. Saya merasakan betul bagaimana semangat Bapak Presiden Jokowi dalam membangun bangsa dengan efektif, efisien, dan transparan. Sehingga di manapun saya berada, di posisi apapun saya bekerja, saya berkomitmen mendukung Presiden dan Pemerintah untuk memajukan NKRI.

Dengan ini, saya juga ingin menjelaskan bahwa saya tidak dapat merespon pertanyaan-pertanyaan media dalam beberapa hari terakhir karena saya ingin fokus dalam menyelesaikan hal ini terlebih dahulu. Terima kasih untuk teman-teman yang telah menghormati dan menghargai keputusan saya tersebut.

Semoga kita semua bisa segera keluar dari masalah pandemi yang berat ini.

Wassalamualaikum warahmatullahi wabarakaatuh” (Devara 2020).
Ruangguru mengklaim perusahaannya sebagai perusahaan teknologi terbesar di Indonesia yang berfokus pada layanan berbasis pendidikan. Mereka telah memiliki lebih dari 15 juta pengguna serta mengelola 300.000 guru yang menawarkan jasa lebih dari 100 bidang pelajaran (Ruangguru 2018).

Selain itu, Ruangguru juga mengembangan produk terbaru, yakni Skill Academy. Skill Academy merupakan platform pelatihan online dan offline bersertifikat bagi mahasiswa dan karyawan yang ingin mengembangkan soft skill. Lagi-lagi, Ruangguru mengklaim platform ini sebagai yang terbesar di Indonesia. Hingga akhirnya pada 2020 ketika wabah melanda, platform ini semakin menjadi perbincangan karena keterkaitannya dengan kisruh Kartu Prakerja.

Kartu Prakerja adalah bantuan biaya pelatihan bagi masyarakat Indonesia yang ingin memiliki atau meningkatkan keterampilan (Kartu Prakerja 2020). Program ini pada awalnya dikhususkan untuk masyarakat yang berusia 18 tahun ke atas dan tidak sedang sekolah atau kuliah. Hal tersebut bertujuan agar para pencari kerja usia muda dapat merasakan langkah pertama dunia kerja yang selanjutnya membantu mereka menghadapi masa depan yang lebih baik. Namun, saat pandemi Covid-19 ini untuk sementara waktu Kartu Prakerja akan diprioritaskan bagi pekerja maupun pelaku usaha mikro/kecil yang terdampak penghidupannya (prakerja.go.id).

Adapun penelitian ini bertujuan untuk mengkaji tentang manajemen isu yang dilakukan oleh Ruangguru terhadap polemik 
kartu prakerja. Adapun unggahan pada media sosial Ruangguru berupa "Surat Terbuka Belva Devara, CEO Ruangguru" akan dianalisis lebih lanjut dalam penelitian ini. Oleh karenanya, penelitian ini akan mengulas manajemen isu yang dilakukan oleh Ruangguru terhadap polemik Kartu Prakerja melalui unggahan media sosial "Surat Terbuka Belva Devara, CEO Ruangguru". Kemudian, penelitian ini juga akan menggambarkan framing yang dibangun oleh Ruangguru melalui unggahan media sosial "Surat Terbuka Belva Devara, CEO Ruangguru" terhadap polemik Kartu Prakerja.

Penelitian bidang komunikasi terkait polemik Ruangguru dan Kartu Prakerja belum banyak ditemukan. Oleh karena itu, polemik ini menarik minat penulis untuk melakukan penelitian. Polemik ini memiliki keunikan karena berlangsung di tengah kondisi pandemi dan di saat sebagian besar masyarakat menengah ke bawah menantikan manfaat atas program Kartu Prakerja yang ditawarkan. Meski demikiaan, penelitian tentang membangun agenda dan isu media dalam ranah PR politik sebelumnya pernah penulis temukan dalam artikel (Myslik et al. 2019) yang berujudul Two Tales of One Crash: Intergovernmental Media Relations and Agenda Building During The Smolensk Airplane Crash. Namun, penelitiannya hanya fokus dalam mencari pengaruh pemberitaan media saja menggunakan metodologi kuantitatif (Myslik et al. 2019).

Dapat dijelaskan, pembingkaian atau framing merupakan istilah yang biasa digunakan untuk membangun, menyampaikan, menafsirkan, atau mengevaluasi informasi yang ada. Strategi ini merupakan cara bagaimana realitas atau dunia dibentuk dan disederhanakan sedemikian rupa untuk ditampilkan kepada khalayak penonton atau pembaca (Hartiana 2014).

Dalam konsepsi Entman menjelaskan bahwa framing merupakan sebuah "paradigma yang retak". Banyak pendapat lain yang beranggapan bahwa ini dikarenakan banyaknya perspektif yang membuat konsep ini menarik secara intelektual dan bermanfaat secara pragmatis (Hallahan 2011).

Kenyataanya, framing telah muncul sebagai model dominan dalam penelitian efek media. Hal ini mendorong audiens membuat "skema penafsiran" yang memungkinkan individu untuk menemukan, memahami, mengidentifikasi, dan melabeli informasi yang ada di lingkungan (Mason 2016).

Framing (Hallahan 1999) memiliki tujuh pendekatan yang sangat membantu komunikasi media. Adapun ketujuh pendekatan ini, yaitu situasi, atribut, risiko, tindakan yang mendukung argumen, masalah, tanggung jawab, dan cerita.

Pertama, framing situasi dalam konteks politik menciptakan situasi di mana tokoh politik berinteraksi dengan orang lain, contohnya seperti pidato, debat, wawancara, dan lain-lain. Dalam pembingkaian ini sering juga dijadikan momen untuk para tokoh politik mendramatisasi dan memanipulasi kendali berbagai situasi.

Kedua, framing atribusi melibatkan penggunaan bahasa dalam pesan itu sendiri. 
Dalam hal ini melibatkan karakteristik obyek, label, dan analogi seperti metafora. Tidak hanya itu, atribut juga dapat dibingkai menggunakan angka seperti statistik dan persentase. Bahasa dan angka merupakan hal yang harus diperhatikan oleh politisi dan komunikator politik.

Ketiga, framing risiko berkaitan dengan teori prospek yang mana orang cenderung menghindari risiko ketika suatu pilihan dinyatakan dalam untung tetapi akan mengambil risiko lebih besar ketika pilihan dinyatakan dalam bentuk kerugian. Hal ini dapat disimpulkan bahwa kekuatan informasi negatif membantu keefektifitasan serangan politik dan juga iklan politik yang negatif.

Keempat, framing tindakan yang mendukung argumen digunakan untuk mengetahui apakah seseorang lebih mudah dibujuk saat terdapat pemberitaan atau klaim dalam konteks positif versus negatif. Hal tersebut sangat menentukan alternatif mana yang lebih persuasif untuk membuat preferensi politik mereka serta rencana untuk memilih.

Kelima, framing masalah atau isu memainkan peran penting khususnya dalam debat politik tentang alokasi sumber daya politik, ekonomi, dan sosial. Hal tersebut terkait dengan identifikasi masalah, identifikasi solusi, dan identifikasi panggilan untuk bertindak dan keterlibatan masyarakat.

Keenam, framing tanggung jawab melibatkan berbagai penilaian bias seperti kesalahan atirbusi mendasar, bias aktorpengamat, bias mementingkan diri sendiri atau individu serta bias kontrol pribadi. Keempat hal tersebut harus dipahami oleh komunikator politik sejauh mana mereka terlibat.

Ketujuh, framing cerita merupakan aplikasi pembingkaian komunikasi politik yang terakhir. Bercerita merupakan cara sederhana yang baik untuk mengkomunikasikan informasi dan tentunya akan lebih efektif jika memperhatikan penggunaan makna, norma, dan nilai yang beresonansi secara budaya.

Di samping ketujuh pendekatan framing Hallahan yang banyak digunakan untuk membantu komunikasi media, penelitian ini juga melihat isu sebagai pendekatan untuk menganalisis interpretasi atas realitas sosial. Kemunculan isu seringkali menimbulkan masalah sosial dan perdebatan yang di dalamnya memiliki berbagai pilihan istilah (interpretasi) oleh pihak-pihak yang berbeda. Isu yang beredar kebanyakan dimulai dari pemberitaan media. Hal ini tentu saja patut untuk diperhatikan karena dalam sebuah berita akan mampu mempengaruhi citra perusahaan (Hartiana 2014).

Penulis pun memandang, upaya Devara membagikan surat terbuka di laman media sosial Instagram sebagai upaya political public relations. Political public relations merupakan proses manajemen yang dilakukan organisasi demi tujuan politik melalui komunikasi dan tindakan yang berupaya membangun dan memelihara hubungan komunikasi untuk memperbaiki reputasinya di mata publik (Myslik et al. 2019).

Terdapat lima langkah yang bisa dilakukan perusahaan untuk mengatasi krisis pada public relations. Pertama, perusahaan 
yang sedang mengalami krisis sebaiknya cepat memberi respon kepada publik. Kedua, perusahaan harus memberikan informasi yang jujur karena publik akan lebih mudah memaafkan kesalahan apabila perusahaan itu jujur daripada perusahaan tersebut berbohong. Ketiga, penting bagi perusahaan untuk selalu informatif karena seperti juga masyarakat, media akan menciptakan cerita versi mereka sendiri apabila perusahaan tidak memberikan informasi mengatakan yang sebenarnya. Keempat, penting untuk memperlihatkan kepada publik kepedulian karena publik akan memaafkan jika perusahaan peduli pada korban krisis. Kelima, memelihara hubungan baik. Ini penting karena perusahaan bisa mempelajari banyak pendapat masyarakat dengan mendengarkan. Sejatinya menyelesaikan krisis harus bersifat kontekstual daripada konseptual (Carlina dan Paramita 2017).

Selebihnya, konten dari surat akan penulis analisa menggunakan analisis framing untuk menjawab pertanyaan penelitian. Perbedaan penelitian ini dengan penelitian sebelumnya yang telah diteliti terletak pada beberapa poin. Pertama, penelitian ini fokus dalam manajemen isu yang dilakukan oleh Ruangguru sebagai suatu organisasi/ perusahaan sebelum isu tersebut berkembang menjadi krisis. Kedua, penulis menganalisis pembingkaian pesan yang dilakukan oleh Ruangguru yang merupakan pusat isu dan bukan pembingkaian yang dilakukan oleh media. Ketiga, penulis menggunakan analisis framing model Entman yang dideskripsikan kembali ke dalam kategori framing berdasarkan Hallahan, sehingga analisis lebih holistik.

\section{Metode Penelitian}

Penelitian ini menggunakan metodologi riset kualitatif. Penelitian kualitatif bertujuan untuk menjelaskan fenomena dengan sedalam-dalamnya melalui pengumpulan data sedalam-dalamnya. Kualitatif menekankan persoalan kedalaman (kualitas) data, bukan banyaknya (kuantitas) data. Dalam penelitian kualitatif dinilai bahwa tidak ada realitas tunggal. Realitas dipandang secara dinamis dan terbentuk karenanya telah melalui konstruksi sosial (Kriyantono 2009). Oleh karena itu, penulis menilai metodologi ini relevan diterapkan untuk menjawab pertanyaan penelitian.

Berdasarkan metodologi kualitatif, dikenal beberapa metode riset. Namun secara spesifik, penelitian kualitatif ini difokuskan pada penggunaan metode analisis teks media. Dengan menggunakan metode ini, penulis menghimpun dokumentasi dalam bentuk teks unggahan media sosial $C E O$ Ruangguru yang berisi pernyataan pengunduran diri bertajuk "Surat Terbuka Belva Devara, CEO Ruangguru" sebagai respons dari polemik Kartu Prakerja yang menyeret nama Ruangguru dan sang CEO.

Data dalam bentuk teks tersebut kemudian akan diteliti menggunakan analisis framing. Framing adalah sebuah strategi untuk membentuk/membangun/membingkai suatu realitas sedemikian rupa dan membingkai pesan yang akan ditampilkan kepada khalayak (Hartiana 2014). Framing banyak digunakan 
sebagai pendekatan untuk mengetahui bagaimana perspektif atau cara pandang yang digunakan wartawan ketika menyeleksi isu dan menulis berita.

Dalam pembahasan mengenai surat terbuka CEO Ruangguru, penulis akan menggunakan analisis framing sebagai pendekatan untuk mengetahui perspektif atau cara pandang yang digunakan Ruangguru ketika menyeleksi isu dan menulis surat terbuka tersebut (Sobur 2006). Penulis menggunakan teknik framing yang diperkenalkan Robert Entman dalam empat skema, yakni problem identification, causal identification, make moral judgement, dan treatment recomendation (Sobur 2006), sebagaimana pada Gambar 1 berikut:

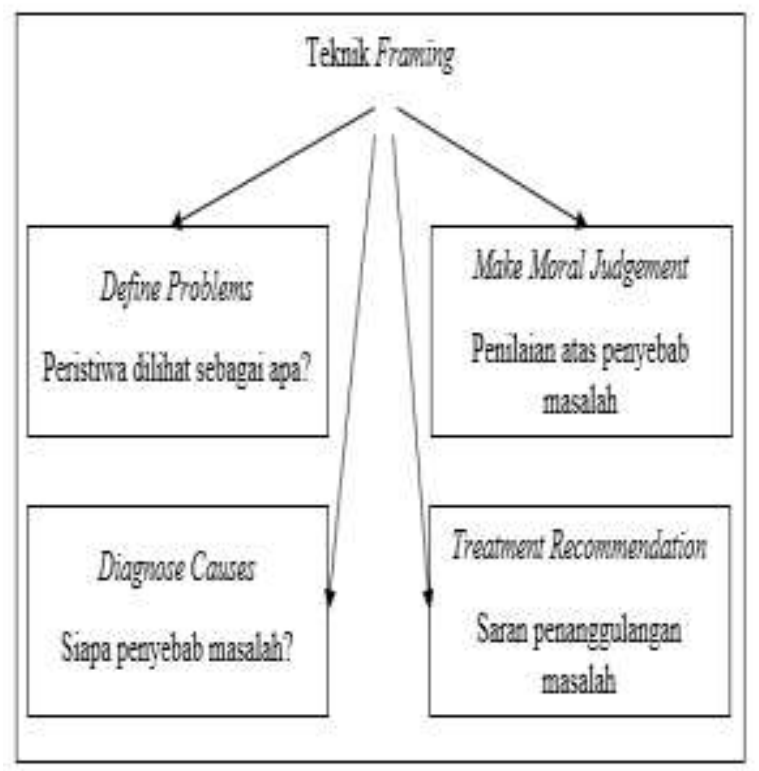

Gambar 1. Skema Teknik Framing Robert Entman

Sumber: (Sobur 2006, hal. 173)

Selanjutnya, penulis akan membuat deskripsi secara sistematis, faktual, dan akurat tentang fakta-fakta dan sifat-sifat populasi atau objek tertentu. Riset ini berusaha menggambarkan realitas yang sedang terjadi tanpa menjelaskan hubungan antarvariabel (Kriyantono 2009). Inilah sebabnya, penulis menggunakan teknik pembingkaian atau framing sebagai pisau bedahnya.

\section{Hasil dan Pembahasan}

Ruangguru memiliki tagline "Bimbel Online Nomor 1 di Indonesia". Tagline ini tentu merupakan cita-cita Ruangguru untuk menjadi penyedia jasa bimbingan belajar terbaik di Indonesia. Untuk mencapai hal tersebut, tentunya Ruangguru tidak menginginkan adanya pemberitaan ataupun isu negatif terlebih isu negatif yang berpotensi menciptakan polemik berkepanjangan, karena tentunya juga akan berpengaruh buruk terhadap perusahaan.

Pada kenyataannya baru-baru ini Ruangguru diterpa isu negatif. Ruangguru terseret dalam isu sensitif yang menyangkut konflik kepentingan dimana isu tersebut tentunya harus segera ditangani oleh Ruangguru. Oleh karenanya, terhadap isu negatif terkait polemik Kartu Prakerja yang diperbincangangkan oleh khalayak, Ruangguru melakukan manajemen isu. Manajemen isu yang dilakukan oleh Ruangguru salah satunya adalah melalui surat terbuka yang diunggah oleh Belva Devara, CEO Ruangguru di media sosial baik Instagram maupun Twitter. Kedua media ini sering digunakan oleh masyarakat dalam hal pertukaran wacana, hal ini juga yang menjadikan unggahan mengenai "Surat Terbuka" tersebut dengan cepat mendapat perhatian. 
Pemberitaan yang cepat menuntut Ruangguru untuk bertindak cepat dan memberikan klarifikasi. Isu yang dialami Ruangguru termasuk ke dalam isu defensif karena berpotensi menimbulkan ancaman bagi perusahaan sehingga perusahaan harus melakukan pertahanan diri agar terhindar/meminimalisir kerugian. Kerugian disini diartikan sebagai memburuknya reputasi dan menurunnya kredibilitas perusahaan di mata publik yang menurunkan tingkat kepercayaan publik terhadap perusahaan.

Manajemen isu yang dilakukan oleh Ruangguru juga dilakukan dengan mengintegrasikan situs web Ruangguru dengan laman FAQ tentang keterlibatan Ruangguru dalam program Kartu Prakerja. Laman tersebut berisi pertanyaan, jawaban dan kesimpulan terkait polemik Kartu Prakerja yang sedang terjadi. Daftar pertanyaan yang tercantum menggambarkan poin-poin keingintahuan masyarakat terhadap isu yang beredar. Dengan adanya laman tersebut, Ruangguru berupaya meng-counter isu yang beredar dengan menegaskannya pada setiap baris "kesimpulan". Artinya melalui pernyataan di dalam konten resminya, Ruangguru telah mensortir informasi dan membentuk pesan-pesan tertentu kepada khalayak.

Analisis framing pada umumnya digunakan untuk menganalisis teks media. Pada dasarnya framing merupakan metode untuk mengetahui bagaimana cara media menceritakan suatu peristiwa dengan melihat bagaimana peristiwa dipahami dan dibingkai oleh media. Dalam praktiknya, tidak hanya pihak media yang melakukan framing dalam menyampaikan pesan, framing pun juga dapat dilakukan oleh organisasi/perusahaan.

Pernyataan resmi yang disampaikan oleh organisasi pun baik itu melalui siaran pers atau situs web perusahaan juga merupakan sebuah konstruksi atas realitas. Organisasi mengemas pesan yang mereka sampaikan dengan frame tertentu yang bertujuan untuk mendefinisikan suatu peristiwa atau isu dan bertujuan untuk mempengaruhi opini publik sehingga tercipta citra organisasi yang positif. Entman memandang framing dalam dua dimensi yakni seleksi isu dan penekanan atau penonjolan aspek-aspek tertentu dari sebuah isu. Cara pandang seperti itu menentukan fakta apa yang hendak diambil, bagian mana yang hendak ditonjolkan dan dihilangkan, dan hendak dibawa ke mana isi informasi tersebut.

Dalam konsepsi Entman, framing pada dasarnya merujuk pada pemberian definisi, memperkirakan masalah.. Analisis terhadap manajemen isu oleh Ruangguru terkait polemik Kartu Prakerja dengan teknik framing Entman adalah sebagai berikut:

Define Problem. Ruangguru menilai bahwa polemik Kartu Prakerja merupakan isu yang harus diatasi. Ruangguru menyadari bahwa perusahaan yang bergerak di bidang jasa rentan terhadap risiko reputasi. Oleh karena itu, Ruangguru berupaya meminimalisasi dampak isu negatif tersebut guna memperkuat klaim "bebas konflik kepentingan" dalam polemik Kartu Prakerja. Pernyataan yang disampaikan oleh Devara melalui media sosialnya dan dimuat di situs web Ruangguru telah melalui perencanaan 
yang matang. Berikut adalah penekanan pada kalimat-kalimat pernyataan, pada kata-kata yang dicetak tebal (oleh penulis) merupakan kunci dari pesan yang hendak disampaikan:

“.... Seperti yang telah dijelaskan
oleh Kementerian Koordinator
Perekonomian dan Manajemen
Pelaksana Kartu Prakerja, proses
verifikasi semua mitra kartu prakerja
sudah berjalan sesuai aturan yang
berlaku, dan tidak ada keterlibatan
yang memunculkan konflik
kepentingan......" (Devara, 2020).

Kata-kata "sesuai aturan" dan "tidak ada keterlibatan" mengandung makna sanggahan atas tudingan berbagai pihak mengenai adanya konflik kepentingan dan trading influence terkait dengan dirinya sebagai staf khusus dan soal terpilihnya Ruangguru sebagai mitra Kartu Prakerja. Dalam "Surat Terbuka Belva Devara", kutipan itu terletak setelah paragraf pernyataan pengunduran diri dari posisi staf khusus Presiden. Artinya, Devara berusaha menjelaskan, pengunduran dirinya bukanlah sikap membenarkan tudingan tentang konflik kepentingan dan trading influence. Jadi, Devara melihat polemik ini sebagai sebuah tudingan yang tidak berdasar saja.

Diagnoses Causes. Ruangguru menganggap bahwa polemik Kartu Prakerja selain dipicu oleh beragamnya asumsi/persepsi masyarakat, juga dipicu akibat masyarakat belum benar-benar memahami bahwa proses pemilihan pelatihan dilakukan secara langsung oleh peserta. Ruangguru menganggap hal ini perlu diluruskan sesegera mungkin. Berikut adalah kata-kata yang dicetak tebal (oleh penulis) merupakan kunci dari pesan yang hendak disampaikan:

“... Pemilihan pun dilakukan
langsung oleh peserta pemegang
Kartu Prakerja.saya tidak ingin
polemik mengenai asumsi/persepsi
publik yang bervariasi tentang posisi
saya sebagai Staf Khusus Presiden
menjadi berkepanjangan, yang dapat
mengakibatkan terpecahnya
konsentrasi Bapak Presiden dan
seluruh jajaran pemerintahan dalam
menghadapi masalah pandemi Covid-
19”(Devara, 2020).

Dari sini dapat dilihat, Devara berusaha menjelaskan penyebab masalah ini bukanlah dari pihak Ruangguru yang memanfaatkan posisi dirinya sebagai Staf Khusus. Devara sebagai CEO Ruangguru melihat penyebab polemik ini adalah asumsi atau persepsi publik yang berkembang dari berbagai sumber informasi.

Make Moral Judgement. Devara berusaha menciptakan nilai moral "pengorbanan" dan "mengalah" dalam polemik yang melibatkan namanya dan Ruangguru. Berikut kutipannya:

"Namun, saya mengambil keputusan yang berat ini karena saya tidak ingin polemik mengenai asumsi/persepsi publik yang bervariasi tentang posisi saya sebagai Staf Khusus Presiden menjadi berkepanjangan, yang dapat mengakibatkan terpecahnya konsentrasi Bapak Presiden dan seluruh jajaran pemerintahan dalam menghadapi masalah pandemi COVID-19" (Devara, 2020).

Dari kutipan itu, tampak Devara berusaha mendeligitimasi langkah pengunduran dirinya pada kutipan kalimat "keputusan yang berat". Ia ingin membingkai pemahaman publik bahwa dia dan Ruangguru 
tidak melakukan hal yang dituduhkan, tetapi ia berusaha mengalah dengan cara mengundurkan diri agar polemik tidak berkepanjangan.

Ia pun melegitimasi tindakan pengunduran dirinya sebagai bentuk pengorbanan dalam polemik ini agar Presiden dan jajaran pemerintahan bisa fokus menangani masalah pandemi Covid-19. Hal ini dapat dilihat dari kutipan kalimat "terpecahnya konsentrasi presiden dan seluruh jajaran pemerintahan".

Treatment Recommendation. Untuk menjaga citra Ruangguru sebagai perusahaan rintisan milenial yang bebas dari nepotisme, sekaligus menekankan independensinya maka Devara mengambil langkah untuk mencegah polemik berkepanjangan yang bergulir di tengah masyarakat yang berpotensi merusak citra Ruangguru. Pernyataan terdapat pada kalimat-kalimat berikut. Bagian yang dicetak tebal (oleh penulis) merupakan kata-kata kunci dalam kalimat tersebut:

“... Saya berterima kasih kepada Bapak Presiden Joko Widodo yang telah memahami dan menerima pengunduran diri saya..." (Devara, 2020).

Devara juga menonjolkan komitmen untuk tetap berkontribusi demi kemajuan bangsa sesuai dengan nilai-nilai perusahaannya yaitu Ruangguru. Bagian yang dicetak tebal (oleh penulis) merupakan katakata kunci dalam kalimat:

“... sungguh banyak pengalaman dan pelajaran yang saya dapatkan dari pekerjaan sebagai Stafsus Presiden. Saya merasakan betul bagaimana semangat Bapak Presiden Jokowi dalam membangun bangsa dengan efektif, efisien, dan transparan. Sehingga di manapun saya berada, di posisi apapun saya bekerja, saya berkomitmen mendukung Presiden dan Pemerintah untuk memajukan NKRI” (Devara, 2020).

Pada paragraf terakhir di surat terbuka yang ditulis Devara, ia menjelaskan bahwa ia tidak merespon dan berbicara di media bukan karena bersembunyi, tetapi ingin fokus menyelesaikan polemik yang menyeret namanya dan perusahaannya. Hal ini tampak pada kutipan berikut:

"Dengan ini, saya juga ingin menjelaskan bahwa saya tidak dapat merespon pertanyaan-pertanyaan media dalam beberapa hari terakhir karena saya ingin fokus dalam menyelesaikan hal ini terlebih dahulu" (Devara, 2020).

Menurut penulis, Devara memandang langkah berbicara kepada media dalam situasi yang masih "panas" bukanlah solusi. Oleh karena itu, ia memilih menyelesaikan masalahnya tanpa sorotan media. Secara tidak langsung, ia pun berusaha menjelaskan kepada publik persoalan dan polemik itu sebenarnya sudah ia selesaikan tanpa digembor-gemborkan, sehingga tidak perlu lagi dipersoalkan. Hal ini tampak pada kalimat penutupnya, Devara mengucapkan terima kasih kepada media dan masyarakat yang telah menghormati dan menghargai keputusannya, serta berdoa agar semua orang bisa keluar dari pandemi.

Menelaah polemik serupa, terjadi pada kasus "Lumpur Lapindo" yang melibatkan sosok Abu Rizal Bakrie selaku petinggi Bakrie Group sekaligus Menteri 
Koordinasi Kesejahteraan Rakyat kala itu serta tokoh politik dari Partai Golkar. Semburan lumpur Lapindo dikategorikan sebagai bencana alam jenis mud volcano berdasarkan hasil kajian BPPT dengan institusi terkait dalam loka karya pada 6 Oktober 2006 dan 20-21 Februari 2007 (Budi 2008). Meski begitu, Bakrie Group tetap berupaya melakukan manajemen isu dengan mengedepankan generousity disertai peliputan berbagai media mengenai belas kasih Keluarga Bakrie terhadap warga terdampak. Pemerintah memang telah melakukan ganti rugi, tetapi rupanya pihak Bakrie juga melakukan pendekatan dengan membeli lahan dan bangunan milik warga yang terdampak. Meski masih membekas dalam ingatan, kenyataannya strategi Bakri Group berhasil meredakan polemik dan usahanya terus berjalan hingga saat ini.

Sebagai CEO, Belva Devara adalah representasi sesungguhnya Ruangguru. Berdasarkan 7 jenis framing Hallahan (1999), manajemen isu yang dilakukan oleh Ruangguru melalui "Surat Terbuka" Devara berusaha membingkai pesan yang tergolong dalam frame situasi, frame atribusi, frame tanggung jawab dan frame cerita.

Frame situasi dapat dilihat dari judul unggahan Devara pada media sosial Instagram dan Twitter yang mengandung unsur dramatisasi. Pemilihan kata-kata "surat terbuka" terkesan lebih mengandung kesan sincerity apabila dibandingkan dengan kata "klarifikasi". Lewat unggahannya tersebut, Bevara juga membingkai inisiatif menyudahi polemik dengan adanya penekanan bahwa ada urgency lainnya yang lebih mendesak dibandingkan harus terus berlarut-larut dalam polemik Kartu Prakerja, yaitu penanggulangan Covid-19.

Frame atribusi menjadi cara bagi organisasi memposisikan diri. Dalam hal ini, Ruangguru yang identik dengan sosok Devara memposisikan bahwa Ruangguru merupakan perusahan rintisan anak bangsa yang bebas dari segala kepentingan politik. Untuk mempertegas positioning tersebut, Devara menekankan bahwa verifikasi Ruangguru sebagai mitra kerja telah berjalan sesuai aturan. Ia pun menutupnya dengan komitmen untuk tetap mendukung program pemerintah meskipun dirinya tidak lagi menjabat sebagai Staf Khusus Presiden RI.

Sementara, frame tanggung jawab merupakan cara organisasi menunjukkan wujud tanggung jawab sesuai dengan kapasitas organisasi. Ruangguru merupakan platform pendidikan berbasis digital. Sebagai CEO dari perusahaan yang bergerak di bidang pendidikan, sudah semestinya Devara memberikan teladan yang baik. Apalagi, pengguna Ruangguru sebagian besar berasal dari kalangan usia pelajar yang rata-rata menggunakan media sosial.

Berkaitan dengan status rangkap jabatan yang sempat dialami oleh Devara, Devara membingkai pesan dalam surat terbuka yang diunggahnya bahwa polemik ini dimulai dari asumsi/persepsi beragam dari masyakat terhadap status jabatannya. Oleh karenanya, dalam surat terbuka yang diunggahnya ia merupakan pihak yang harus bertanggung jawab terhadap keberlangsungan 
Ruangguru. Pilihannya hanya ada 2, yaitu tetap bertahan dengan status rangkap jabatan di bidang politik sebagai Staf Khusus dan di bidang bisnis sebagai seorang $C E O$ dengan konsekuensi polemik Kartu Prakerja terus bergulir yang pada akhirnya mengancam kelangsungan Ruangguru, ataukah memilih untuk mengundurkan diri dari jabatan Staf Khusus dengan konsekuensi kredibilitas Ruangguru tidak semakin tercoreng akibat polemik Kartu Prakerja dan bisa meredakan polemik tersebut.

Frame cerita. Dengan penjelasan yang runut pada surat terbuka yang diunggah oleh Devara, ia membimbing masyarakat untuk lebih mendalami polemik yang terjadi. Dapat dilihat dari struktur pada unggahan Devara, mulai dari kutipan atas pernyataan Airlangga Hartanto dan PMO tentang verifikasi yang telah sesuai aturan, penyebab polemik adalah asumsi/persepsi beragam di masyarakat, rasa terima kasih kepada Presiden RI atas kesempatan berharga yang pernah dialaminya, upaya menyudahi polemik dan membuat kondisi kondusif dengan cara mengundurkan diri, menjaga kredibilitas Ruangguru dan kredibilitas dirinya dengan menjaga independensi, hingga wujud komitmen untuk mengabdi kepada tanah air tanpa terlibat langsung di ranah politik.

Dari runut cerita surat terbuka yang diunggah, Devara berhasil membangun sebuah cerita tentang sikap mengalah dan pengorbanan. Dimana dua sikap ini bermakna positif yang sering disematkan pada "tokoh protagonis" dalam mitos dan dongeng yang sering dilemahkan oleh tokoh antagonis.
Meski begitu, Devara berhasil menyusun kata dan kalimat dengan apik tanpa menyinggung pihak manapun. Oleh karena itu, organisasi perlu memiliki kemampuan dalam menentukan strategi memilih, menonjolkan dan menghubungkan fakta ke dalam bentuk pesan agar lebih bermakna, lebih menarik dan lebih berarti sehingga pesan tersebut dapat mengubah opini yang selama ini terbentuk dari terpaan isu negatif.

\section{Simpulan}

Manajemen isu merupakan hal yang penting untuk dilakukan oleh organisasi atau perusahaan. Terlebih, apabila sedang dihadapkan pada polemik, organisasi dituntut untuk merespons isu secara cepat dengan cara yang tepat demi keberlangsungan organisasi.

Dalam polemik Kartu Prakerja, manajemen isu yang dilakukan oleh Ruangguru cukup efektif dengan membingkainya melalui sebuah surat terbuka yang diunggah Devara di media sosial. Langkah ini ternyata efektif menyurutkan isu mengenai Ruangguru dalam polemik tersebut. Dengan mengimplementasikan manajemen isu melalui framing sedemikian rupa di media sosial, Ruangguru dapat memposisikan diri dalam polemik dan mengelola isu dengan baik sehingga tidak mengakibatkan polemik berkepanjangan.

Meskipun analisis framing identik dengan penelitian pada ranah media dan jurnalistik. Namun, apabila berangkat dari salah satu kata kunci dalam framing, yakni konstruksi atas realitas, maka analisis framing bisa saja digunakan dalam penelitian lainnya. 
Termasuk penelitian pada ranah organisasi atau perusahaan, seperti yang dilakukan oleh penulis.

Tentu saja, penelitian mengenai manajemen isu yang dilakukan Ruangguru terhadap polemik Kartu Prakerja melalui unggahan Surat Terbuka Belva Devara dalam sudut pandang analisis framing, baru salah satu langkah yang dilakukan perusahaan tersebut. Oleh karena itu, perlu adanya penelitian lanjutan dalam objek, kasus, atau pun metode yang berbeda untuk lebih memahami mengenai manajemen isu yang dilakukan Ruangguru.

\section{Daftar Pustaka}

Budi, Kurniasih. 2008. "BPPT Simpulkan Lumpur Lapindo Bencana Alam." Tempo.Co. 2008. https://nasional.tempo.co/read/119419/bp pt-simpulkan-lumpur-lapindo-bencanaalam.

Carlina, Gladys, and Sinta Paramita. 2017. "PR Crisis Melalui Media Social." Jurnal Komunikasi 9 (1). https://doi.org/10.24912/jk.v9i1.211.

Devara, Belva. 2020. "Surat Terbuka Belva Devara, CEO Ruangguru." Jakarta: www.kompas.tv. 2020. https://www.kompas.tv/article/77313/isisurat-terbuka-belva-terkait-pengundurandiri-dari-stafsus.

Hallahan, Kirk. 1999. "Seven Models of Framing: Implications for Public Relations." Journal of Public Relations Review $11 \quad$ (3): 205-42. https://doi.org/https://doi.org/10.1207/s1 532754xjprr1103_02.

\footnotetext{
. 2011. Political Public Relation and Strategic Framing. New York: Routledge.
}

Hartiana, Theresia Intan Putri. 2014. "Citra Perusahaan Dalam Berita Krisis
Perusahaan: Konstruksi Citra Perusahaan Daerah Taman Satwa (PDTS) Kebun Binatang Surabaya Dalam Teks Berita Kematian Michael Di Harian Jawa Pos Dan Sindo." Jurnal Kajian Komunikasi 2 (2).

https://doi.org/https://doi.org/10.24198/jk k.v2i2.7379.

Kartu Prakerja. 2020. “Apa Itu Kartu Prakerja?" Www.Prakerja.Go.Id. 2020. https://www.prakerja.go.id/tentang-kami.

Kriyantono, Rachmat. 2009. Teknik Praktis Riset Komunikasi. Jakarta: Kencana.

Mason, Alicia. 2016. "Media Frames and Crisis Events: Understanding the Impact on Corporate Reputations, Responsibility Attributions, and Negative Affect." International Journal of Business Communication $\quad 56 \quad$ (3). https://doi.org/https://doi.org/10.1177/23 29488416648951.

Myslik, Barbara, Liudmila Khalitova, Tianduo Zhang, and Sophia Tarasevich. 2019. "Two Tales of One Crash: Intergovernmental Media Relations and Agenda Building During The Smolensk Airplane Crash." The International Communication Gazette. https://doi.org/https://doi.org/10.1177/17 48048519853766.

Rizal, Jawahir Gustav. 2020. "Kebijakan Kartu Prakerja Dinilai Tak Efektif, Ekonom: Lebih Terasa Diberikan Bantuan Langsung." Www.Kompas.Com. 2020. https://www.kompas.com/tren/read/2020/ 04/17/213716365/kebijakan-kartuprakerja-dinilai-tak-efektif-ekonomlebih-terasa-diberikan?page $=$ all .

Ruangguru. 2018. "Tentang Ruangguru." Ruangguru.Com. 2018. https://ruangguru.com/general/about?utm _source=bimbelrg\&utm_medium=referra 1\&utm_campaign=footer.

Sobur, Alex. 2006. Analisis Teks Media. Bandung: PT Remaja Rosdakarya. 